\author{
Kateryna Osmolyk \\ Methodist of IT in Education Laboratory \\ Borys Grinchenko Kyiv University, Kyiv, Ukraine \\ k.osmolyk@kubg.edu.ua \\ ORCID: 0000-0002-1816-9299
}

\title{
INFTUENCE OF E-LEARNING ON THE DEVELOPMENT OF THE COUNTRY
}

\begin{abstract}
With development of information and communication technologies in the world appears the question of changes in education system, the question of changes in the system of training, and retraining of competitive and highly skilled specialists for the modern labor market. One of the most promising and developing forms of modern training is the technology of elearning. Each specialist and master affects not only his own financial life, but also the development of the whole country. That is why the problem of the impact of the development of IC technologies, in particular e-learning on the development of the country, is relevant.
\end{abstract}

Keywords: e-learning; IC technologies; IC tools; country; development; influence

Introduction. Every society recreates itself through a system of education. Education as a social and cultural phenomenon is an integral part of the development of mankind. In the information society, the quality of education becomes the main argument of the economic development of society as a whole, providing such a level of life and professional competence of a person that would satisfy, first of all, its needs, as well as the needs of society and the state.

State policy in the field of education is an integral part of national policy. Everything that happens in society, nature, development of human culture, affects the formation and implementation of educational policy, the functioning of the education system as a whole.

With the development of IC technologies and e-learning, the problem of interconnection and interaction between state development and the latest technology is quite significant and relevant. Today, e-learning is an integral part of the initial process, and it is realized with the help of IC technologies.

Analysis of recent studies and publications. In pedagogy today there is no clearly definition of term "e-learning", often under this word people understand studying with help of information and communication technologies. There are many terms and definitions that describe e-learning - online learning, learning via Internet, distance learning and many others. Let's consider several interpretations of the concept of "e-learning":

According to oxford dictionary it is

Learning conducted via electronic media, usually on the Internet (Oxford Living Dictionary, 2017).

learning done by studying at home using computers and courses provided on the internet (Cambridge Dictionary, 2017).

UNESCO experts define e-learning as a process of getting new knowledge and skills through information and communication technologies. (Summary Report - Unesco, 2006). And they consider that E-learning is a cornerstone for building inclusive knowledge societies (UNESCO, 2017).

Understanding eLearning is simple. eLearning is learning using electronic technologies to access educational curriculum outside of a traditional classroom. In most cases, it refers to a course, program or degree delivered completely online. We define eLearning courses that are specifically delivered through the internet to somewhere other than the classroom where the professor teaches. It is not a course delivered via a DVD or CD-ROM, video tape or over a television channel. It's interactive in that you can also communicate with your teachers, professors or other students in your class. Sometimes it is delivered live, where you can "electronically" raise your hand and interact in real time, and sometimes it is a lecture that has 
been pre-recorded. There is always a teacher or professor interacting / communicating with you and grading your participation, your assignments and your tests. eLearning has been proven to be a successful method of training and education is becoming a way of life for many citizens (ELearningNC 2017).

There is a lot of descriptions that emphasize other aspects of e-Learning. Here are some of them:

e-Learning - A wide range of applications and processes that provide: training based on the use of web-technologies; training, built with the use of a personal computer, virtual classrooms; and means of organizing the interaction of users over the network. e-Learning includes the delivery of educational content through the Internet, audio and video, satellite broadcasting, interactive television.

e-Learning is training built using information and telecommunication technologies. It covers different kinds of activities, from supporting the learning process, to delivering educational content to the audience.

Education via the Internet, network, or standalone computer. e-learning is essentially the network-enabled transfer of skills and knowledge. e-learning refers to using electronic applications and processes to learn. e-learning applications and processes include Web-based learning, computer-based learning, virtual classrooms and digital collaboration. Content is delivered via the Internet, intranet/extranet, audio or video tape, satellite TV, and CD-ROM (Rosenberg, 2007).

E-learning was first called "Internet-Based training" then "Web-Based Training" Today you will still find these terms being used, along with variations of e-learning such as elearning, Elearning, and eLearning (Webopedia, 2017).

About e-learning, a recent good definition is given in "Open Learning Today",

"E-Learning is the effective learning process created by combining digitally delivered content with (learning) support and services" (ODLQC, 2017).

E-learning The term e-learning is a generic expression for all learning involving the use of information and communication technologies (ICT) to support both learning and teaching. Its meaning here, therefore, is normally synonymous with ICT-based learning. The term may refer to the use of various technologies and tools to support learning in different contexts, including face-to-face settings and distance learning, separately or in combination, in which case e-learning is usually called blended learning. (Gaebel, 2014)

In our research, we will define e-learning as "the use of information and communication technologies (ICTs) to improve the quality of learning through improved access to learning resources and services, as well as remote collaboration" (Morze, 2014)

The article's goal. The description of the influence of e-learning, with all its advantages and disadvantages, on the individual and personal development; and its impact on the development of the country.

Advantages and disadvantages of distance learning. Trends in e-learning development. E-learning is impossible without the use of IC technologies. The advantages of learning using IC technologies include:

1. Personalization

2. Opportunity of on-the-job training.

3. Ability to combine educational content to form various training programs adapted for a particular student.

4. Ability to get much more information necessary for assessing the knowledge, skills and abilities received as a result of training.

5. Lower cost.

6. Using a wide range of different learning tools.

7. Opportunity for people with special needs and disabilities to study. 
8. Providing access to quality education for individuals, which do not have the opportunity to study in traditional form.

9. More effective learning management system based on the possibility to collect much more information.

The disadvantages of e-learning include:

1. The difficulties in operational changes, if the training has already begun.

2. Students' motivation is not always strong.

3. Need for investment in building an e-learning environment.

4. Strong dependence on technical infrastructure. Failure in the infrastructure can lead to reduction in efficiency or even disruption of learning.

5. Lack of specialists in the field of e-learning technologies.

6. High investment in making changes to educational content.

The development of a new educational direction has brought new challenges and problems. The further development of e-learning technologies depends on how successfully the existing problems will be solved (Rosenberg, 2007).

It can be distinguished such key problems in the field of e-learning as:

- the problem of determining the equivalence of distance courses and the accepting of distance education in line with traditional full-time education;

- a language problem during importing (exporting) education. Distance courses are designed in one language, will require significant investments for their translation into another language, including the need to take into account the social, cultural and other characteristics of the region where e-learning will be;

- uneven development of information technologies. Low capacity of data channels seriously limits the possibility of using e-learning tools;

- lack of highly skilled experts in the field of e-learning technologies;

- high cost of development and support of e-learning courses;

- difference in time in the case of distance learning in large areas. This becomes especially relevant when using e-learning tools that operate in real time;

- large number of underdeveloped organizations that provide e-learning technologies but do not have the appropriate competence in this subject.

Today, e-learning in Ukraine can fully develop in the presence of a regulatory framework; educational institutions of e-learning; contingent of students; qualified teachers; training programs and courses; appropriate material and technical base; financial support, etc.

Educational researches in our country and around the world show the urgent need to stimulate e-learning to ensure its dynamic and progressive development and implementation at all levels of education, first of all, higher, because e-learning is an innovative technology aimed at professionalization and increasing the mobility of those who study, and at the present stage of ICT development it can be considered as a technological basis for the fundamentalization of higher education (Kyanovskaya, 2015).

Modern e-learning and its influence in developing the potential of each individual. Modern e-learning is based on the use of Internet technologies. The question of the impact of Internet technologies on the formation of the student's personality is extremely important today, because these IC technologies leads to the informational relationships in society, dictate new conditions for the cooperation between the individual and the world.

Many teachers, psychologists and other professionals tell about negative Internet environment's impact on the formation of the student's personality, because Internet content is sometimes negative and destructive. In addition, it is possible to state the uncontrolled use of Internet resources by students, in particular computer games, television entertainment programs, which leads to decrease in the criticality accepting of the received information and, as a result, an undervaluation of the role of books, arts, music, etc. Therefore, it is extremely 
important to develop an independent attitude to information, conscious approach to material selection, and an adequate assessment of low-yield products. After all, the future of the younger generation depends on the quality of the information received, the ability to analyze and evaluate it.

At the same time, researchers point out the positive impact of the latest technologies on the formation youth moral development. It is impossible to imagine modern life without ITC usage. Because of this, experts from various fields of knowledge believe that all efforts should be directed towards finding equal e-learning courses and materials for students' development, ways of using modern information technologies, ways of adequate understanding of materials, but with the preservation of their own personal integrity. It requires not only the knowledge of modern IC tools for getting information and the ability to work with them, but also the skills of independent work with these resources, the high level of critical thinking, the creative abilities of students, the ability to navigate in a single educational space. Because of this, experts are trying to find ways to accepting new information materials by the students. Although they do not consider the Internet space to be completely safe, they are looking for such reserves that will be psychologically favorable for schoolchildren, because today, these tools are not just for communication, but trey are important way to find educational information.

We can state that in the conditions of the modern information space, the functioning of quality education is impossible without the use of Internet technologies, in particular in the process of e-learning. Modern technologies affect the formation of the personality of the student, contribute to its cultural enrichment and artistic and aesthetic development, but it is possible with the growth of literacy of students in the work with communication networks, development of skills competently to handle information resources, to critically perceive and to select from the huge stream the necessary information and navigate it. Learning with the use of IC technologies has a huge educational potential, when they are used, the formation of a new personality that is able to think critically, navigate in the modern educational space is taking place.

E-learning impact on the development of the country. Every society recreates itself through a system of education. Education as a social and cultural phenomenon is an integral part of the development of mankind.

Each state consists of citizens. Each citizen influences society that forms the country. There is huge interconnection and interaction between each citizen and the country. That is why the state is interested in providing high-quality educational services and raising highly qualified specialists. Without these factors, it is impossible to create civilian country and a society.

Civil society is community of free, independent, equal people, each of them state provides legal opportunities to be the owner, enjoy economic freedom and reliable social protection, other rights and freedoms, take an active part in political life and other areas of human and citizen's life. (Kopeichikov, 2003)

The state should create equal conditions for the self-personalization of the individual, promote the growth of its creative forces and progressive efforts. This is one of the main activities of the state. "The rights and freedoms of a person and their guarantees determine the content and direction of the state. The state is responsible to a person for his activities. The approval and guarantee of human rights and freedoms is the main responsibility of the state" (Constitution of Ukraine, Article 3).

The introduction of e-learning technologies into the educational process creates additional conditions for improving the quality of education through:

- development and use of innovative educational teaching technologies;

- differentiation of educational process for the most complete development of 
personality abilities, disclosure of its creative potential;

- organization of effective collective educational activities, including extraterritorial and joint international (education without borders);

- expansion of e-space and increase of free access to informational educational resources;

- creation of a new generation of electronic teaching aids;

- development methods of evaluating the results of educational activities and management education.

The need of implementation pedagogical process that trains professionals of a wide profile, able to navigate in many areas of human activity and teach themselves is the main goal of modernizing the education system and the main psychological and pedagogical factor in the development of e-learning (Ognevyuk, Sysoieva, 2015).

Let's look at the rating of the best Universities in the world. (fig. 1).

\begin{tabular}{|c|c|c|c|c|c|}
\hline $\begin{array}{l}\text { Higher } \\
\text { Education } \\
\text { Network } \\
\text { QS rankings } 2018\end{array}$ & \multicolumn{5}{|c|}{$\begin{array}{l}\text { Higher education data specialists QS rank the top } 200 \text { world universities } \\
\text { Top } 200 \text { universities in the world - the UK's rise and fall } \\
\text { UK universities fall down global league tables after budget cuts } \\
\text { View the QS subject rankings } 2017 \\
\text { Explore the complete QS top } 200 \text { rankings and their methodology }\end{array}$} \\
\hline \multicolumn{6}{|l|}{$<$} \\
\hline \multirow[t]{11}{*}{$\begin{array}{l}\text { Wednesday } 7 \text { June } 2017 \\
21.00 \text { BST }\end{array}$} & 2018 rank & 2017 rank & Institution name & Country & $\begin{array}{c}\text { Overall } \\
\text { Score }\end{array}$ \\
\hline & 1 & 1 & $\begin{array}{l}\text { Massachusetts Institute of Technology } \\
\text { (MIT) }\end{array}$ & United States & 100 \\
\hline & 2 & 2 & Stanford University & United States & 98.7 \\
\hline & 3 & 3 & Harvard University & United States & 98.4 \\
\hline & 4 & 5 & $\begin{array}{l}\text { California Institute of Technology } \\
\text { (Caltech) }\end{array}$ & United States & 97.7 \\
\hline & 5 & 4 & University of Cambridge & United Kingdom & 95.6 \\
\hline & 6 & 6 & University of Oxford & United Kingdom & 95.3 \\
\hline & 7 & 7 & UCL (University College London) & United Kingdom & 94.6 \\
\hline & 8 & 9 & Imperial College London & United Kingdom & 93.7 \\
\hline & 9 & 10 & University of Chicago & United States & 93.5 \\
\hline & 10 & 8 & $\begin{array}{l}\text { ETH Zurich (Swiss Federal Institute of } \\
\text { Technology) }\end{array}$ & Switzerland & 93.3 \\
\hline
\end{tabular}

Fig. 1. Rating of the Universities (QS Ranking, 2017).

As we see in the ranking the leading universities are the institutions from the most developed world countries. As we see the quality of education directly depends on the funds spend on it.

Conclusions. Today it becomes clear that the main indicator of the economic development of society should be considered improving the quality of training qualified professionals in various areas of public life. The quality of education - the main component of human capital - is a fundamental element of competitiveness and sustainable development of 
the country. Low level of education's quality and specialists' qualifications are reflected, of course, on the efficiency of the economy. The modernization of educational processes in the information society is aimed, first of all, at achieving a high level of quality education, which is a fundamental element of human competitiveness in the global world, and, therefore, the main factor in the economic development of the country. That is why the issue of providing quality educational services should become a priority in public policy. But at the same time, with the development of the IC technologies and trends in education, it is very difficult to provide these services qualitatively without the use of IC technologies and e-learning. That is why we should take into account the influence and interruption between the development of IC technologies, e-learning, distance learning and the development of the whole country.

\section{REFERENCES}

Ognevyuk, V. \& Sysoieva, S. (2015). Training of education experts in Ukraine. Ukrainian-Polish Yearbook. 2015, 7-7

http://osvitologia.kubg.edu.ua/en/numbers/25-archive-2015/45-42015.html?showall=\&start=9 (in Ukranian)

Morze, N. \& Balyk, N. (2014). Analysis of foreign and domestic education programmes for elearning managers. Edukacja Humanistyczna, 2, 123-137. http://mobile.elar.fizmat.tnpu.edu.ua/bitstream/handle/123456789/960/EH_Elearning-NMNB-EST-v3.pdf?sequence $=1$ (in Russian)

Gaebel, M., Kupriyanova, V., Morais, R. \& Colucci, E. (2014). E-learning in European Higher Education Institution. November 2014.

http://www.eua.be/Libraries/publication/e-learning_survey

Kyanovskaya, N. (2015). The concept of e-learning in the context of modern pedagogical science.

http://www.rusnauka.com/29_DWS_2012/Pedagogica/1_120037.doc.htm (in Ukrainian)

Kopeichikov, V. (2003). Science of law. Textbook. Kyiv, (Chapter 5)

http://www.ebk.net.ua/Book/BookPravothnavstvo/Glava2/R1G2par5.htm (in Ukrainian)

Rosenberg, M. (2007). Beyond E-Learning: New Approaches to Managing and

Delivering Organizational Knowledge. Atlanta International Conference. Atlanta.

Cambridge Dictionary (2017).

http://dictionary.cambridge.org/dictionary/english/e-learning

ICT in Education. UNESCO (2017).

http://www.unesco.org/new/en/unesco/themes/icts/e-learning/

Oxford Living Dictionary (2017).

https://en.oxforddictionaries.com/definition/us/e-learning

Webopedia. E-learning. (2017).

http://www.webopedia.com/TERM/E/e learning.html

What is E-learning. ELearningNC (2017).

http://www.elearningnc.gov/about_elearning/what_is_elearning/

The Open Distant Learning Quality Council. E-learning. (2017).

https://www.odlqc.org.uk/open-distance-learning-quality-council

Ranking universities in Ukraine "Top-200 Ukraine" (2017). May 29, 2017. http://www.euroosvita.net/index.php/?category=1\&id=5209 (in Ukrainian)

Top 200 Universities of the World. (2017). QS Ranking 2018. https://www.theguardian.com/higher-education-network/2017/jun/07/top-200-universities-inthe-world-2018-the-table

Constitution of Ukraine. Article 3. (1991)

http://constitution.gov.ua/proposals/3 (in Ukrainian)

The Law of Ukraine on Higher Education (2017). April 16, 2017. 
http://zakon4.rada.gov.ua/laws/show/1556-18 (in Ukrainian) 